\title{
LAND SNAIL COMMUNITIES AT LAKE HAŃCZA (NE. POLAND)
}

\author{
BEATA M. POKRYSZKO ${ }^{1}$, ROBERT A. D. CAMERON ${ }^{2}$
}

\author{
${ }^{1}$ Museum of Natural History, Wrocław University, Sienkiewicza 21, 50-335 Wrocław, Poland \\ (e-mail: bepok@biol.uni.wroc.pl) \\ ${ }^{2}$ Department of Animal and Plant Sciences, University of Sheffield, Sheffield S10 2TN, UK, \\ Department of Zoology, The Natural History Museum. London SW7 5BD, UK
}

\begin{abstract}
The snail fauna of human-transformed forests (originally ranging from oak-hornbeam to alder swamps) at Lake Hańcza and two nearby lakes in NE. Poland includes 29 species, with 14-18 species per site. There are also four slug species. The ten sampling sites vary rather much in their species composition, the mean Nei index being 0.71 and $\mathrm{I}_{\mathrm{MAX}} 1.57$; the heterogeneity does not seem to result from sampling error. In most sites 1-3 species contribute over $50 \%$ of total abundance. Most species recorded are common, euryoecious and widely distributed; restricted forest snails, timber-dwellers and vegetation climbers are nearly absent.
\end{abstract}

KEY WORDS: terrestrial snails, NE. Poland, Suwałki Lakeland, forests

\section{INTRODUCTION}

Compared to southern Poland, the northern part of the country is believed to have a poor terrestrial malacofauna. It was probably this belief that resulted in the north being much less studied, though the reverse may also be true. It follows from RIEDEL's 1988 catalogue that 90 out of the total of 175 terrestrial gastropods of Poland were recorded from the northern third of the country on various occasions. However, the localities are few, most locality data are imprecise, and some records are doubtful (cf. RIEDEL 1988, WIKTOR 2004). The situation has not changed much since the publication of the 1988 catalogue. The north-eastern corner of the country seems to be the most neglected. Only three of the 33 faunistic and/or ecological papers (DYDUCH 1980, DZIĘCZKOWSKI
1988, CAMERON \& POKRYSZKO 2004; for further references see RiEdel 1988, CAMERON \& POKRYSZKo 2004) on various forests in northern Poland deal with the north-eastern part of the country, and all three focus on Białowieża Forest. This is the first attempt at providing some data on terrestrial gastropod communities of the Suwałki Lakeland.

In summer 2003, when sampling terrestrial gastropods within the project "Geographical variation in the composition and richness of forest snail faunas in northern Europe", we visited Lake Hańcza and examined snail fauna in ten sites. The faunal list has been used for broader comparisons (POKRYSZKO \& CAMERON 2005), here we present detailed results.

became a nature reserve (GŁOWACIŃSKI 1968); in 1976 the surrounding area was proclaimed a landscape park (RA_KOWSKI 1989). The lake has a complicated shoreline and mostly steep shores. It is sur- the north-easternmost $\left(54^{\circ} 16^{\prime} \mathrm{N}, 2^{\circ} 49^{\prime} \mathrm{E}\right)$ part of the Suwałki Lakeland (Fig. 1). Because of its unique character, in 1963 the lake, but not its surroundings,

\section{STUDY AREA AND HABITATS SAMPLED}

Lake Hańcza, the deepest in Poland, is located in 

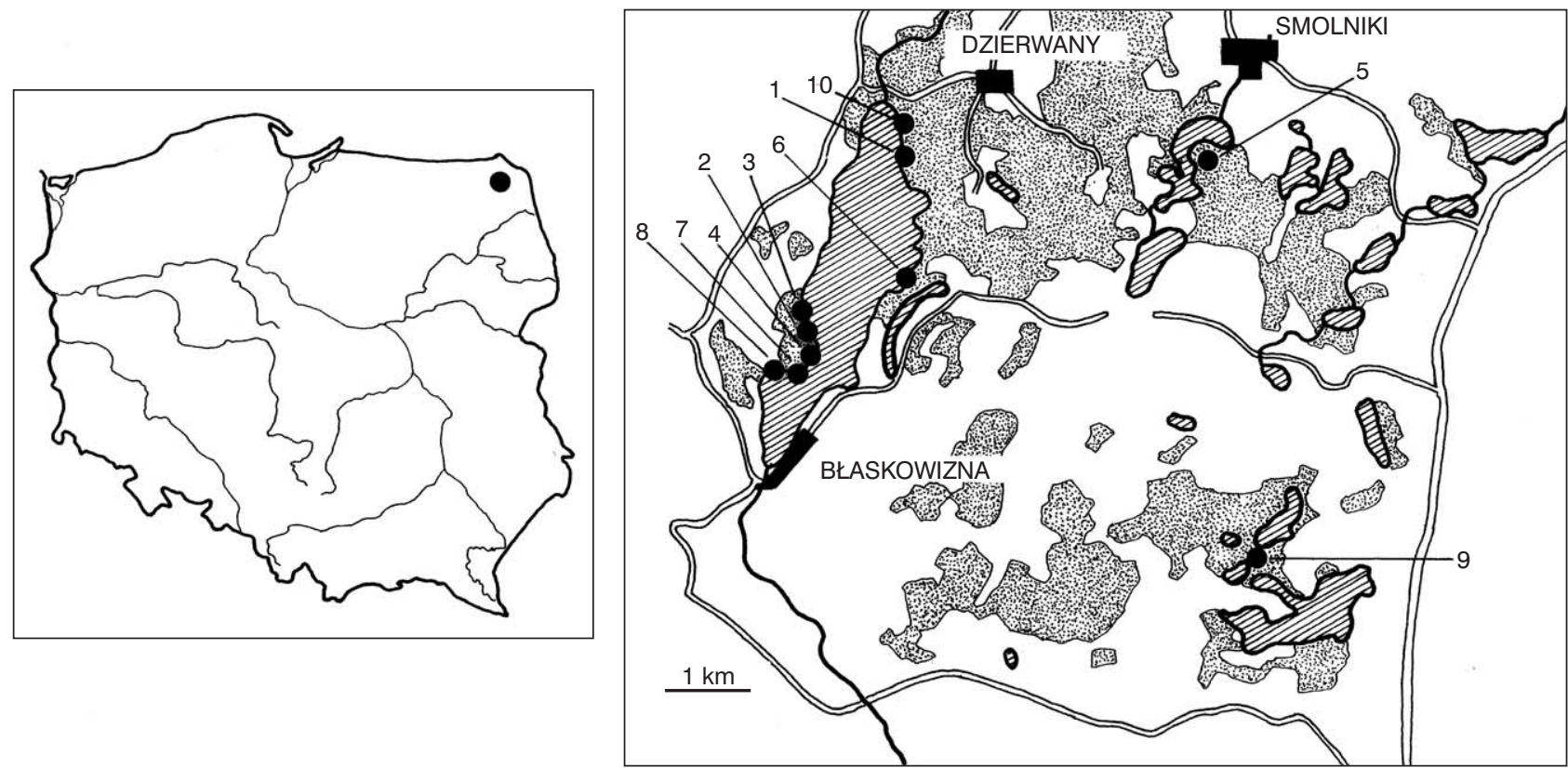

Fig. 1. Study area (left: solid circle) and location of sampling sites (right: solid circles; forest areas stippled, lakes hatched)

rounded by a narrow belt of forest and adjoined by moraine hills.

Originally, the forests of the region were oak-hornbeam, riverine forests with ash and linden, alder forests, and pine-oak or pine stands in drier places. Dur-

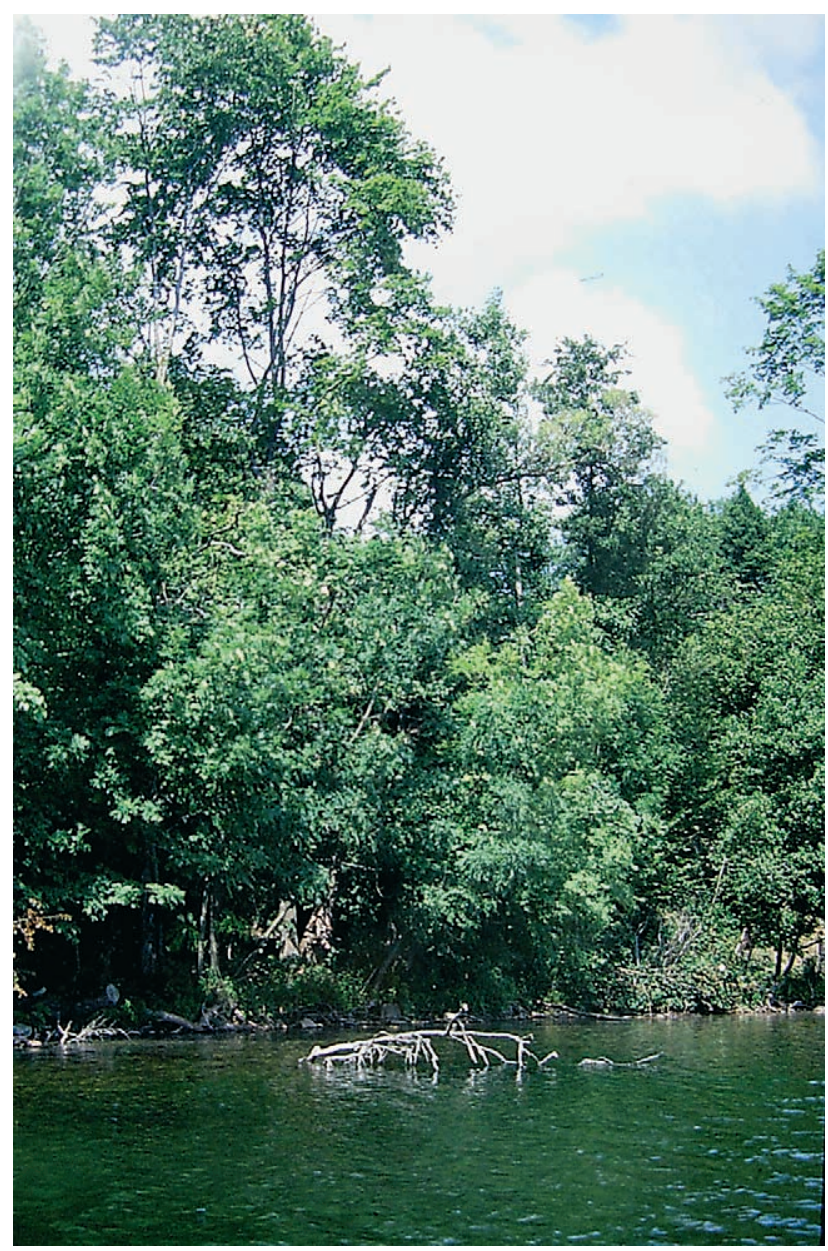

ing the last 500 years most of them, especially deciduous stands, growing on fertile soil, were clear-felled and converted into arable land. The narrow belts of forests surrounding Hańcza and smaller lakes in its vicinity range from transformed oak-hornbeam stands (often with some linden and ash) to alder swamps (Figs 2, 3). They have never been completely clear-felled (as suggested by the occurrence of plants such as Paris quadrifolia), but in most places are rather heavily affected by removal of dead timber, some logging and cattle or horse grazing. Cows, horses and their dung were encountered while sampling. Forest only $30 \mathrm{~m}$ or more away from the lake shore is usually heavily managed, and is predominantly pine or spruce.

Fig. 1 shows the sampling sites. All sites, except 5 (Lake Jaczno) and 9 (Lake Jegłówek) were located on the shores of Lake Hańcza:

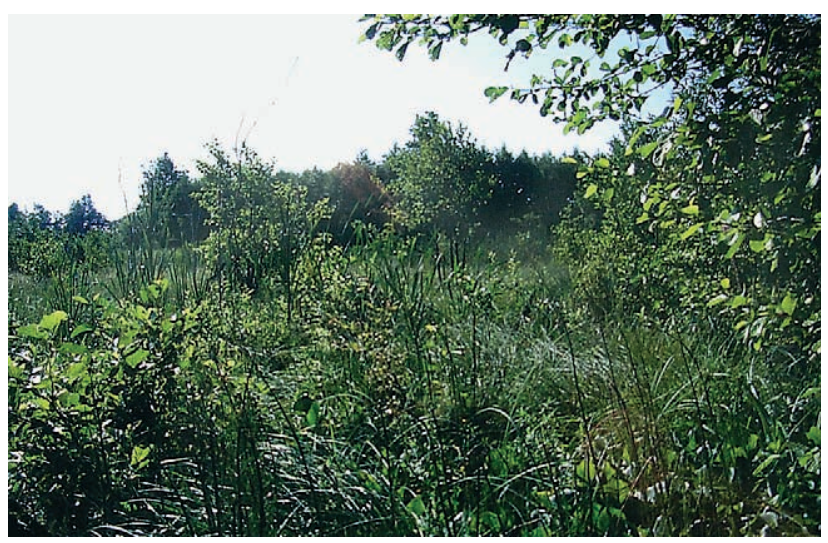

Figs 2, 3. A fragment of a forest (1) and an alder swamp (2) at lake Hańcza 
1. E. shore of Lake Hańcza, steep slope with linden, alder, elm, hazel, birch, oak, sedges and Herb Paris, $\mathrm{pH}$ 5.5;

2. W. shore of Lake Hańcza, gentle slope with linden, alder, maple, hazel, birch, ash and nettles;

3. W. shore of Lake Hańcza, gentle slope with linden, alder, hazel, ash and birch, $\mathrm{pH}$ 6.0;

4. W. shore of Lake Hańcza, flat shore with linden, alder, ash, elm, cow-wheat and Iris;

5. E. shore of Lake Jaczno: flat, swampy lake margin with standing water pools: alder and a few ash and birch trees, sedges, ferns;

6. E. shore of Lake Hańcza: partly open swamp, with traces of horse grazing, alder, ash, hazel, Iris, meadowsweet and nettles;

\section{METHODS}

Sampling was carried out in July 2003. Each site was an area of c. $400 \mathrm{~m}^{2}$, chosen to represent a typical part of the surrounding vegetation. Within each site snails and slugs were collected by eye. Two people searched in this way, in all appropriate microhabitats, for at least one hour at each site. In addition, c. 201 of litter was collected from patches within each site. The litter was sieved $(10 \times 10 \mathrm{~mm}$ mesh); the coarsest fraction was searched by eye in the field and discarded. The remainder was bagged and taken to the laboratory, where it was air-dried, sieved and sorted down to $0.5 \mathrm{~mm}$ mesh. Large helicoids were sometimes counted but not collected; slugs were identified in the field or specimens preserved for identification in the laboratory. No attempt was made to count the number of slugs, as daytime sampling is notoriously unreliable (WÄREBORN 1969). Tests for completeness of sampling followed CAMERON \& POKRYSZKO (2005).

\section{RESULTS AND DISCUSSION}

A total of 33 species were recorded, 29 snails and four slugs (Table 1); three: Succinea oblonga, S. sarsii and Cochlicopa nitens, were limited to alder swamps. The snail species list seems to be complete, as indicated by the Chao estimator for the whole set of sites equal to about one species missed, by the shape of the rank abundance curve (Fig. 4), which steepens rapidly as the rarest species are included, and by the fact that the numbers of specimens per site are usually ten times or more higher than the number of species (CAMERON \& POKRYSZKO 2005). The species composition varies rather much between the sites - the Nei index ranges from 0.50 to 0.91 (mean 0.73) (Table 2,
7. W. shore of Lake Hańcza, gentle slope with alder, ash, hornbeam, elm, maple, nettles, wild strawberries and Circaea;

8. W. shore of Lake Hańcza, gentle slope: hornbeam coppice with Phragmites fringe with rowan, some alder, ash, willows, aspen, bracken and wood sorrel;

9. betwen lakes Jegłówek and Szurpiły, gentle slope with young elm, hazel, ash, birch, some alder at lake shore (traces of cattle trampling), wood sorrel;

10.E. shore of Lake Hańcza, gentle slope with wet flushes: alder, ash, elm, hazel, poplars, wild raspberry and sedges.

Soil pH was determined colorimetrically for residues for two sites. From the flora and litter texture, it seems likely that the other non-swamp sites would yield similar values.

To estimate similarity among the snail faunas in sites we used the Nei index $\mathrm{I}_{\mathrm{N}}=$ number of species in common/geometric mean of the number of species present in each site. Additionally, we applied the Marczewski-Steinhaus distance (ALEXANDROWICZ 1987). Slugs are omitted, as sampling is not so reliable, but adding them makes little difference to the results. Overall heterogeneity was estimated using Whittaker's index, $\mathrm{I}_{\mathrm{W}}$, the total number of species in the array divided by the mean number per site, and its variant, $\mathrm{I}_{\mathrm{MAX}}$, total number of species divided by that in the richest site (CAMERON \& POKRYSZKO 2004). Slugs are included.

All shells extracted were identified and counted, excluding only very old or unidentifiable remains. Nomenclature throughout follows KERNEY et al. (1983). The samples are kept in the collection of RADC and of the Natural History Museum, Wrocław University.

Fig. 5). The two swamp sites (5 and 6) are rather dissimilar (0.67), the similarity between site 6 and all other sites being $0.50-0.69$, while site 5 is closer to sites 7,9 and $10(0.77,0.79$ and 0.75 , respectively) than it is to 6 . Two clusters of similar sites ( 1 and 10 at $0.91,2,3,4$ and 8 at 0.83 ) are geographically very close. Even excluding the two swamp sites, the lowest Nei value is still only 0.69 . The Marczewski-Steinhaus distances (Table 2) give a very similar picture; they range from 0.17 to 0.67 , and excluding the swamp sites the highest value is 0.55 . The two variants of Whittaker's index, $\mathrm{I}_{\mathrm{W}}$ and $\mathrm{I}_{\mathrm{MAX}}$, are 1.75 and 1.57 for all sites, and 1.55 and 1.43 when swamps are ex- 
Table 1. List of species recorded from Lake Hańcza. For snails, numbers of specimens, relative abundance and frequency are given. For slugs, not counted, presence and frequency are given

\begin{tabular}{|c|c|c|c|c|c|c|c|c|c|c|c|c|}
\hline \multirow{2}{*}{ No. } & Species/Sites & 3 & 4 & 7 & 1 & 9 & 2 & 5 & 8 & 10 & 6 & $\mathrm{~F}$ \\
\hline & \multicolumn{12}{|l|}{ Snails } \\
\hline 1 & Cochlicopa lubrica (O. F. Müll.) & $\begin{array}{c}20 \\
10.31\end{array}$ & $\begin{array}{c}13 \\
6.02\end{array}$ & $\begin{array}{c}26 \\
14.53\end{array}$ & $\begin{array}{c}35 \\
18.52\end{array}$ & $\begin{array}{c}10 \\
5.46\end{array}$ & $\begin{array}{c}45 \\
10.66\end{array}$ & $\begin{array}{c}11 \\
4.82\end{array}$ & $\begin{array}{c}20 \\
16.3\end{array}$ & $\begin{array}{c}41 \\
18.60\end{array}$ & $\begin{array}{c}78 \\
30.00\end{array}$ & 100 \\
\hline 2 & Punctum pygmaeum (Drap.) & $\begin{array}{c}72 \\
37.11\end{array}$ & $\begin{array}{c}27 \\
12.50\end{array}$ & $\begin{array}{c}49 \\
27.37\end{array}$ & $\begin{array}{c}69 \\
36.51\end{array}$ & $\begin{array}{c}16 \\
8.74\end{array}$ & $\begin{array}{c}44 \\
10.43\end{array}$ & $\begin{array}{c}13 \\
5.70\end{array}$ & $\begin{array}{c}4 \\
3.23\end{array}$ & $\begin{array}{c}15 \\
6.61\end{array}$ & $\begin{array}{c}28 \\
10.77\end{array}$ & 100 \\
\hline 3 & Nesovitrea hammonis (Ström) & $\begin{array}{c}33 \\
17.01\end{array}$ & $\begin{array}{c}15 \\
6.94\end{array}$ & $\begin{array}{c}3 \\
1.68\end{array}$ & $\begin{array}{c}16 \\
8.47\end{array}$ & $\begin{array}{c}6 \\
3.28\end{array}$ & $\begin{array}{c}25 \\
5.92\end{array}$ & $\begin{array}{c}30 \\
13.16\end{array}$ & $\begin{array}{c}9 \\
7.26\end{array}$ & $\begin{array}{c}10 \\
4.41\end{array}$ & $\begin{array}{c}5 \\
1.92\end{array}$ & 100 \\
\hline 4 & Nesovitrea petronella (L. Pfeiffer) & $\begin{array}{c}4 \\
2.06\end{array}$ & $\begin{array}{c}3 \\
1.39\end{array}$ & $\begin{array}{c}3 \\
1.68\end{array}$ & $\begin{array}{c}13 \\
6.88\end{array}$ & $\begin{array}{c}14 \\
7.65\end{array}$ & $\begin{array}{c}8 \\
1.90\end{array}$ & $\begin{array}{c}6 \\
2.63\end{array}$ & $\begin{array}{c}1 \\
0.81\end{array}$ & $\begin{array}{c}16 \\
7.05\end{array}$ & $\begin{array}{c}9 \\
3.46\end{array}$ & 100 \\
\hline 5 & Zonitoides nitidus (O. F. Müll.) & $\begin{array}{c}5 \\
2.58\end{array}$ & $\begin{array}{c}5 \\
2.31\end{array}$ & $\begin{array}{l}17 \\
9.5\end{array}$ & $\begin{array}{c}5 \\
2.66\end{array}$ & $\begin{array}{c}11 \\
6.01\end{array}$ & $\begin{array}{c}6 \\
1.42\end{array}$ & $\begin{array}{c}17 \\
7.46\end{array}$ & $\begin{array}{c}4 \\
3.23\end{array}$ & $\begin{array}{c}6 \\
2.64\end{array}$ & $\begin{array}{c}35 \\
13.46\end{array}$ & 100 \\
\hline 6 & Euconulus fulvus (O. F. Müll.) & $\begin{array}{c}12 \\
6.19\end{array}$ & $\begin{array}{c}15 \\
6.94\end{array}$ & $\begin{array}{c}2 \\
1.12\end{array}$ & $\begin{array}{c}16 \\
8.47\end{array}$ & $\begin{array}{c}6 \\
3.28\end{array}$ & $\begin{array}{c}1 \\
0.24\end{array}$ & $\begin{array}{c}20 \\
8.77\end{array}$ & $\begin{array}{c}5 \\
4.03\end{array}$ & $\begin{array}{c}5 \\
2.20\end{array}$ & $\begin{array}{c}15 \\
5.77\end{array}$ & 100 \\
\hline 7 & Cepaea hortensis (O. F. Müll.) & $\begin{array}{c}10 \\
5.15\end{array}$ & $\begin{array}{c}15 \\
6.94\end{array}$ & $\begin{array}{c}20 \\
11.17\end{array}$ & $\begin{array}{c}13 \\
6.88\end{array}$ & $\begin{array}{c}5 \\
2.73\end{array}$ & $\begin{array}{c}18 \\
4.27\end{array}$ & $\begin{array}{c}7 \\
3.07\end{array}$ & $\begin{array}{c}2 \\
1.61\end{array}$ & $\begin{array}{c}16 \\
7.05\end{array}$ & $\begin{array}{c}2 \\
0.77\end{array}$ & 100 \\
\hline 8 & Vertigo pusilla O. F. Müll. & $\begin{array}{c}42 \\
21.65\end{array}$ & $\begin{array}{c}64 \\
29.63\end{array}$ & $\begin{array}{c}22 \\
12.29\end{array}$ & $\begin{array}{c}3 \\
1.59\end{array}$ & $\begin{array}{c}54 \\
29.51\end{array}$ & $\begin{array}{c}33 \\
7.82\end{array}$ & $\begin{array}{c}7 \\
3.07\end{array}$ & $\begin{array}{c}17 \\
13.71\end{array}$ & $\begin{array}{c}4 \\
1.76\end{array}$ & 0 & 90 \\
\hline 9 & Vallonia costata (O. F. Müll.) & $\begin{array}{c}1 \\
0.52\end{array}$ & $\begin{array}{c}4 \\
1.85\end{array}$ & $\begin{array}{c}32 \\
17.88\end{array}$ & $\begin{array}{c}2 \\
1.06\end{array}$ & $\begin{array}{c}14 \\
7.65\end{array}$ & $\begin{array}{c}103 \\
24.41\end{array}$ & $\begin{array}{c}2 \\
0.88\end{array}$ & $\begin{array}{c}5 \\
4.03\end{array}$ & 0 & 0 & 80 \\
\hline 10 & Succinea putris (L.) & $\begin{array}{c}1 \\
0.52\end{array}$ & $\begin{array}{c}8 \\
3.70\end{array}$ & $\begin{array}{c}3 \\
1.68\end{array}$ & $\begin{array}{c}2 \\
1.06\end{array}$ & $\begin{array}{c}2 \\
1.09\end{array}$ & 0 & 0 & $\begin{array}{c}7 \\
5.65\end{array}$ & $\begin{array}{c}14 \\
6.17\end{array}$ & 0 & 70 \\
\hline 11 & Vertigo substriata (Jeffr.) & $\begin{array}{c}21 \\
10.82\end{array}$ & $\begin{array}{c}12 \\
5.56\end{array}$ & 0 & $\begin{array}{c}6 \\
3.17\end{array}$ & $\begin{array}{c}5 \\
2.73\end{array}$ & $\begin{array}{c}2 \\
0.47\end{array}$ & $\begin{array}{c}3 \\
1.32\end{array}$ & 0 & $\begin{array}{c}4 \\
1.76\end{array}$ & 0 & 70 \\
\hline 12 & Vitrina pellucida (O. F. Müll.) & $\begin{array}{c}2 \\
1.03\end{array}$ & 0 & $\begin{array}{c}3 \\
1.68\end{array}$ & 0 & $\begin{array}{c}3 \\
1.64\end{array}$ & $\begin{array}{c}8 \\
1.90\end{array}$ & $\begin{array}{c}3 \\
1.32\end{array}$ & $\begin{array}{c}4 \\
3.23\end{array}$ & 0 & $\begin{array}{c}14 \\
5.38\end{array}$ & 70 \\
\hline 13 & Carychium minimum O. F. Müll. & 0 & 0 & $\begin{array}{c}12 \\
6.70\end{array}$ & $\begin{array}{c}5 \\
2.66\end{array}$ & $\begin{array}{c}26 \\
14.21\end{array}$ & 0 & $\begin{array}{c}76 \\
33.33\end{array}$ & 0 & $\begin{array}{c}16 \\
7.05\end{array}$ & $\begin{array}{c}23 \\
8.85\end{array}$ & 60 \\
\hline 14 & Carychium tridentatum (Risso) & $\begin{array}{c}12 \\
6.19\end{array}$ & 0 & 0 & $\begin{array}{c}22 \\
11.64\end{array}$ & 0 & $\begin{array}{c}69 \\
16.35\end{array}$ & 0 & $\begin{array}{c}9 \\
7.26\end{array}$ & $\begin{array}{c}35 \\
15.42\end{array}$ & $\begin{array}{c}14 \\
5.38\end{array}$ & 60 \\
\hline 15 & Vitrea crystallina (O. F. Müll.) & $\begin{array}{c}3 \\
1.55\end{array}$ & $\begin{array}{c}3 \\
1.39\end{array}$ & 0 & $\begin{array}{c}8 \\
4.23\end{array}$ & 0 & $\begin{array}{c}5 \\
1.18\end{array}$ & $\begin{array}{c}1 \\
0.44\end{array}$ & 0 & $\begin{array}{c}7 \\
3.08\end{array}$ & 0 & 60 \\
\hline 16 & Perforatella bidentata (Gmel.) & $\begin{array}{c}3 \\
1.55\end{array}$ & $\begin{array}{c}8 \\
3.70\end{array}$ & $\begin{array}{c}3 \\
1.68\end{array}$ & $\begin{array}{c}22 \\
11.64\end{array}$ & 0 & 0 & $\begin{array}{c}11 \\
4.82\end{array}$ & 0 & $\begin{array}{c}26 \\
11.45\end{array}$ & 0 & 60 \\
\hline 17 & Acanthinula aculeata (O. F. Müll.) & $\begin{array}{c}1 \\
0.52\end{array}$ & $\begin{array}{c}10 \\
4.63\end{array}$ & 0 & $\begin{array}{c}2 \\
1.06\end{array}$ & 0 & $\begin{array}{c}44 \\
10.43\end{array}$ & 0 & $\begin{array}{c}8 \\
6.45\end{array}$ & 0 & 0 & 50 \\
\hline 18 & Euomphalia strigella (Drap.) & 0 & 0 & $\begin{array}{c}3 \\
1.68\end{array}$ & $\begin{array}{c}2 \\
1.06\end{array}$ & $\begin{array}{c}4 \\
2.19\end{array}$ & $\begin{array}{c}5 \\
1.18\end{array}$ & 0 & 0 & $\begin{array}{c}10 \\
4.41\end{array}$ & 0 & 50 \\
\hline 19 & Cochlicopa lubricella (Porro) & 0 & $\begin{array}{c}9 \\
4.17\end{array}$ & 0 & 0 & $\begin{array}{c}4 \\
2.19\end{array}$ & $\begin{array}{c}23 \\
5.45\end{array}$ & 0 & $\begin{array}{c}3 \\
2.42\end{array}$ & 0 & 0 & 40 \\
\hline 20 & Vertigo antivertigo (Drap.) & 0 & 0 & $\begin{array}{c}1 \\
0.56\end{array}$ & 0 & $\begin{array}{c}1 \\
0.55\end{array}$ & 0 & $\begin{array}{c}4 \\
1.75\end{array}$ & 0 & 0 & $\begin{array}{c}3 \\
1.15\end{array}$ & 40 \\
\hline 21 & Vallonia pulchella (O. F. Müll.) & 0 & $\begin{array}{c}8 \\
3.70\end{array}$ & $\begin{array}{c}8 \\
4.47\end{array}$ & 0 & 0 & 0 & 0 & $\begin{array}{c}8 \\
6.45\end{array}$ & 0 & $\begin{array}{c}18 \\
6.92\end{array}$ & 40 \\
\hline 22 & Columella edentula (Drap.) & 0 & $\begin{array}{c}4 \\
1.85\end{array}$ & $\begin{array}{c}1 \\
0.56\end{array}$ & 0 & 0 & $\begin{array}{c}11 \\
2.61\end{array}$ & 0 & 0 & 0 & 0 & 30 \\
\hline 23 & Discus rotundatus (O. F. Müll.) & $\begin{array}{c}2 \\
1.03\end{array}$ & 0 & $\begin{array}{c}2 \\
1.12\end{array}$ & 0 & 0 & 0 & 0 & $\begin{array}{c}6 \\
4.84\end{array}$ & 0 & 0 & 30 \\
\hline 24 & Aegopinella minor (Stabile) & 0 & $\begin{array}{c}2 \\
0.93\end{array}$ & 0 & 0 & 0 & 0 & 0 & 0 & $\begin{array}{c}1 \\
0.44\end{array}$ & 0 & 20 \\
\hline 25 & Succinea oblonga Drap. & 0 & 0 & 0 & 0 & 0 & 0 & 0 & 0 & 0 & $\begin{array}{c}5 \\
1.92\end{array}$ & 10 \\
\hline 26 & Oxyloma sarsii (Esmark) & 0 & 0 & 0 & 0 & 0 & 0 & 0 & 0 & 0 & $\begin{array}{c}35 \\
14.36 \\
\end{array}$ & 10 \\
\hline
\end{tabular}




\begin{tabular}{|c|c|c|c|c|c|c|c|c|c|c|c|c|}
\hline \multirow{2}{*}{ No. } & Species/Sites & 3 & 4 & 7 & 1 & 9 & 2 & 5 & 8 & 10 & 6 & $\mathrm{~F}$ \\
\hline & \multicolumn{12}{|l|}{ Snails } \\
\hline 27 & Cochlicopa nitens (Gallenstein) & 0 & 0 & 0 & 0 & 0 & 0 & $\begin{array}{c}14 \\
6.14\end{array}$ & 0 & 0 & 0 & 10 \\
\hline 28 & Aegopinella pura (Alder) & $\begin{array}{c}4 \\
2.06\end{array}$ & 0 & 0 & 0 & 0 & 0 & 0 & 0 & 0 & 0 & 10 \\
\hline \multirow[t]{4}{*}{29} & Arianta arbustorum (L.) & 0 & 0 & 0 & 0 & $\begin{array}{c}1 \\
0.55 \\
\end{array}$ & 0 & 0 & 0 & 0 & 0 & 10 \\
\hline & Total species & 18 & 18 & 18 & 17 & 17 & 16 & 16 & 16 & 16 & 14 & \\
\hline & Total specimens & 194 & 216 & 179 & 189 & 183 & 422 & 228 & 124 & 227 & 260 & \\
\hline & \multicolumn{12}{|l|}{ Slugs } \\
\hline 30 & Arion subfuscus (Drap.) & $\mathrm{X}$ & $\mathrm{X}$ & $\mathrm{X}$ & $\mathrm{X}$ & $\mathrm{X}$ & $\mathrm{X}$ & $\mathrm{X}$ & $\mathrm{X}$ & $\mathrm{X}$ & $\mathrm{X}$ & 100 \\
\hline 31 & Arion circumscriptus Johnston & $\mathrm{X}$ & $\mathrm{x}$ & $\mathrm{X}$ & & $\mathrm{X}$ & $\mathrm{X}$ & & & $\mathrm{X}$ & & 60 \\
\hline 32 & Deroceras laeve (O.F. Müll.) & & & & & & & $\mathrm{X}$ & $\mathrm{X}$ & $\mathrm{X}$ & $\mathrm{X}$ & 40 \\
\hline 33 & Malacolimax tenellus (O.F. Müll.) & $\mathrm{X}$ & & $\mathrm{X}$ & $\mathrm{X}$ & & & & & & & 30 \\
\hline & Total slug species & 3 & 2 & 3 & 2 & 2 & 2 & 2 & 2 & 3 & 2 & \\
\hline & Total all species & 21 & 20 & 21 & 19 & 19 & 18 & 18 & 18 & 19 & 16 & \\
\hline
\end{tabular}

Table 2. Values of the Nei index (above the diagonal) and Marczewski-Steinhaus index (below the diagonal) for the studied sites. Swamp site comparisons underlined

\begin{tabular}{|c|c|c|c|c|c|c|c|c|c|c|}
\hline Site & 1 & 2 & 3 & 4 & 5 & 6 & 7 & 8 & 9 & 10 \\
\hline 1 & & 0.83 & 0.86 & 0.80 & $\underline{0.79}$ & $\underline{0.58}$ & 0.74 & 0.73 & 0.76 & 0.91 \\
\hline 2 & 0.26 & & 0.82 & 0.82 & $\underline{0.75}$ & $\underline{0.60}$ & 0.65 & 0.81 & 0.79 & 0.75 \\
\hline 3 & 0.25 & 0.30 & & 0.78 & $\underline{0.77}$ & $\underline{0.57}$ & 0.72 & 0.82 & 0.69 & 0.77 \\
\hline 4 & 0.33 & 0.30 & 0.36 & & $\underline{0.71}$ & $\underline{0.50}$ & 0.72 & 0.77 & 0.69 & 0.77 \\
\hline 5 & $\underline{0.35}$ & $\underline{0.40}$ & $\underline{0.38}$ & $\underline{0.45}$ & & $\underline{0.67}$ & $\underline{0.77}$ & $\underline{0.63}$ & $\underline{0.79}$ & $\underline{0.75}$ \\
\hline 6 & $\underline{0.59}$ & $\underline{0.57}$ & $\underline{0.61}$ & $\underline{0.67}$ & $\underline{0.50}$ & & $\underline{0.69}$ & $\underline{0.67}$ & $\underline{0.65}$ & $\underline{0.60}$ \\
\hline 7 & 0.41 & 0.52 & 0.43 & 0.43 & $\underline{0.38}$ & $\underline{0.48}$ & & 0.77 & 0.80 & 0.71 \\
\hline 8 & 0.43 & 0.32 & 0.30 & 0.38 & $\underline{0.55}$ & $\underline{0.50}$ & 0.38 & & 0.73 & 0.63 \\
\hline 9 & 0.38 & 0.35 & 0.48 & 0.48 & $\underline{0.35}$ & $\underline{0.52}$ & 0.33 & 0.43 & & 0.73 \\
\hline 10 & 0.17 & 0.40 & 0.38 & 0.38 & $\underline{0.40}$ & $\underline{0.57}$ & 0.45 & 0.55 & 0.43 & \\
\hline
\end{tabular}

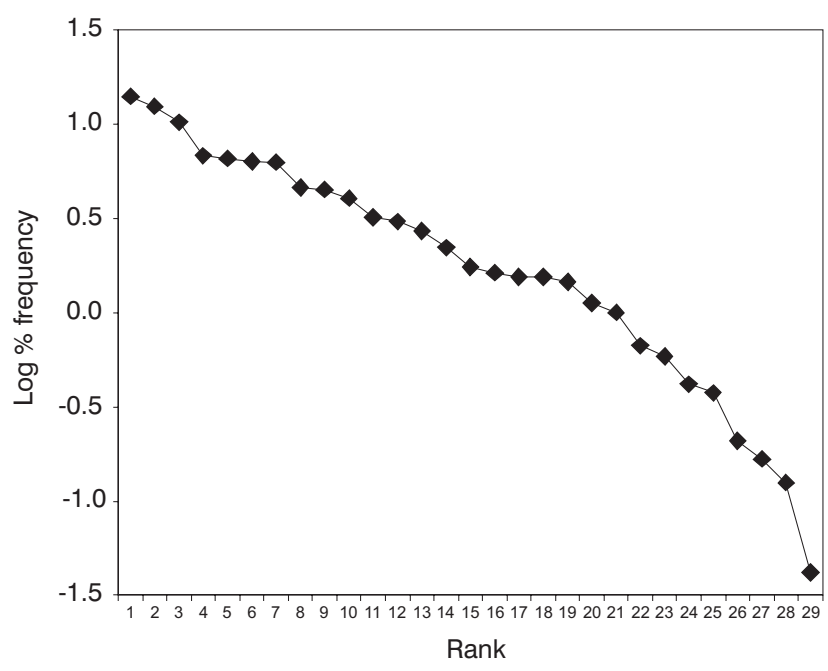

Fig. 4. Logarithmic rank-abundance relationships for snails from all sampling sites. The vertical scale is expressed as $\log _{10}$ percentage of the total

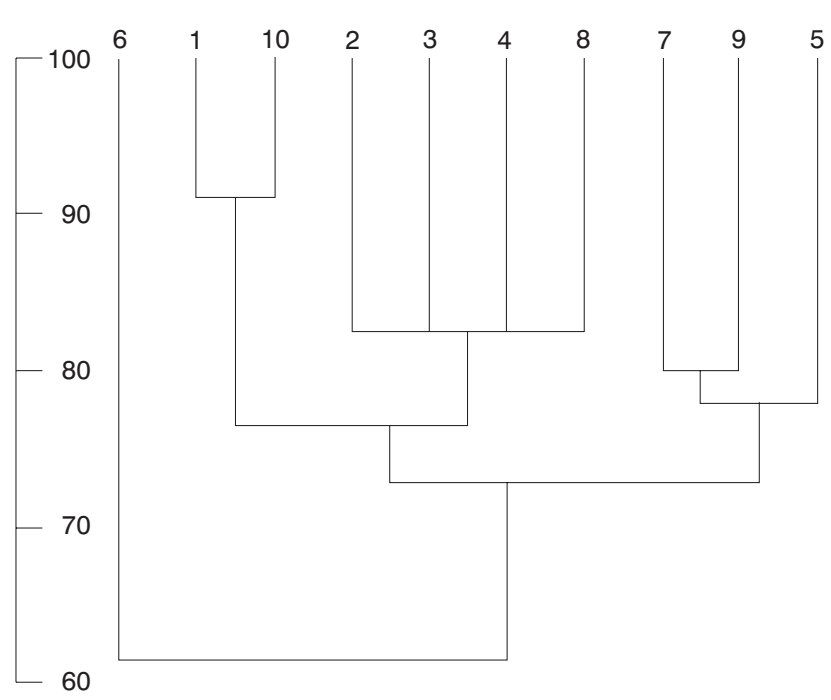

Fig. 5. Dendrogram of Nei affinities for snails among the sites 
cluded. Considering that all the sites are very close together - the lake is only 4,535 $\mathrm{m}$ long, with the maximum width of $1,175 \mathrm{~m}$ and the total shoreline of 12.7 $\mathrm{km}$, and all but two sites ( 4 and $5 \mathrm{~km}$ away from Lake Hańcza) were in its nearest vicinity - they are fairly heterogenous. Where similar clusters of sites are considered across N. Europe, a value of $\mathrm{I}_{\mathrm{MAX}}$ of 1.43 is at the high end of the range (POKRYSZKO \& CAMERON 2005). While this may be influenced by sampling error, the Chao estimator (of species missed) for individual sites ranges from 0 ( 0 or 0.5 for most sites) to 2.25 , with the mean 0.3 , and the patchy distribution appears to be genuine.

The dominance structure in most sites includes 1-3 species which together constitute more than $50 \%$ individuals, all other species being represented by rather few specimens. The dominant species vary between sites: for example, Punctum pygmaeum and Cochlicopa lubrica are the most numerous in three sites each, Vertigo pusilla in two, Vallonia costata and Carychium minimum in one each. These differences may reflect the patchy distribution, or be only temporary, since all these species have short life cycles and highly weather-dependent reproduction (for life history details see WHITNEY 1938, MORTON 1954, WÄREBORN 1979, 1982, ISKRZYŃSKA 1986, BAUR 1989, BULMAN 1990, POKRYSZKO 1990a).

Twelve snail species occur with a high frequency (70-100\%); all of them except Cepaea hortensis and Succinea putris are small-sized and strict litter-dwellers, and none is a genuinely restricted forest snail. Out of nine medium-frequency species (40-60\%), all except Perforatella bidentata and Euomphalia strigella are small-sized; among them only Acanthinula aculeata can be regarded as a genuine forest-dweller. The lowest frequency class $(10-30 \%)$ includes eight species: the three limited to the alder swamps, the plant-climbing Columella edentula (POKRYSZKO 1990b), the forest-dwelling Aegopinella pura, Ae. minor which is very rare in the north of Poland (RIEDEL 1988), the big and vegetation-climbing Arianta arbustorum and Discus rotundatus which is closely associated with rotting timber (KUŹNIK-KOWALSKA 1999). The complete absence of clausiliids, more than ten species of which could be expected to occur in this part of the country (for ranges see RIEDEL 1988, WIKTOR 2004; for clausiliid lists from nearby sites see MARZEC in prep.) is probably also associated with the scarcity of dead timber.
The presence of marsh-loving species (Succinea putris, Vertigo antivertigo, Zonitoides nitidus) even in non-swampy sites reflects the effect of the adjacent lake shore. All the species recorded are widely distributed in Poland, nearly all are euryoecious, and most are common (for distribution and ecology see RIEDEL 1988, WIKTOR 2004). Among the slugs, Arion subfuscus was universal, and none were restricted to one or two sites. Only Malacolimax tenellus can be regarded as a true forest species (WIKTOR 2004).

The nearest locality where samples were taken with the same methods and where the same range of species could be expected, based on the distribution ranges and ecological requirements, is Białowieża Forest (CAMERON \& POKRYSZKo 2004). The total number of snail species found in forest habitats in Białowieża was 46 (plus 6 slugs) and thus c. $35 \%$ higher, with 11 species of clausiliids, eight helicoids and two species of timber-dwelling Discus, both of them frequent and abundant; the number of species per site ranged from 17 to 35 (mean 27). Even the poorest category of forest sampled at Białowieża, Melitto-Carpinetum, more acid than Hańcza forests, is richer overall and in the mean number of species per site. The number of high-frequency (70-100\%) snail species in Białowieża was 22, compared to 12 in Hańcza, eight being the same in both localities. In Białowieża the group included, among others, three clausiliids and two species of Discus. The overall similarity (Nei) between Lake Hańcza and Białowieża is only 0.68 , but discounting the clausiliids, the fauna in the two localities, about $160 \mathrm{~km}$ apart, is very similar: Lake Hańcza and Białowieża have 25 species in common, and their Nei index is 0.92 !

The low species number per site, the predominance of common, euryoecious, widely distributed species, the near-absence of vegetation climbers and the scarcity of timber-dwellers suggest a depauperate community of a narrow and heavily affected belt of once-natural forest. Data from the Pomeranian Lakeland, and from Wielkopolska, show a similar phenomenon: apparently attractive lakeside and swamp forests tend to be depauperate, especially in clausiliids; only a few sites have escaped significant and damaging disturbance (CAMERON \& POKRYSZKO, 2004, 2006). MARZEC (in prep.) will show that such refuges also occur in the northeast.

\section{REFERENCES}

ALEXANDROWICZ S. W. 1987. Analiza malakologiczna w badaniach osadów czwartorzędowych. Zeszyty Naukowe AGH Kraków 1145, Geologia 12: 1-240.

BAUR B. 1989. Growth and reproduction of the minute land snail Punctum pygmaeum (Draparnaud). J. Moll. Stud. 55: 383-387. 
BULMAN K. 1990. Life history of Carychium tridentatum (Risso, 1826) (Gastropoda: Pulmonata: Ellobiidae) in the laboratory. J. Conch. 33: 321-333.

Cameron R. A. D., Pokryszko B. M. 2004. Land mollusc faunas of Białowieża Forest (Poland), and the character and survival of forest faunas in the North European Plain. J. Moll. Stud. 70: 149-164.

Cameron R. A. D., Pokryszko B. M. 2005. Estimating the species richnes and composition of land mollusc communities: problems, consequences and practical advice. J. Conch. 38: 529-547.

CAmeron R. A. D., Pokryszko B. M. 2006. Forest snail faunas in the Kaszuby Uplands (Pomerania): a rich northern refuge. Folia Malacol. 14: 75-82.

DYDUCH A. 1980. Ślimaki lądowe (Gastropoda terrestria) wybranych zbiorowisk roślinnych puszczy Białowieskiej i puszczy Niepołomickiej. Ochrona Przyrody 43: 223-272.

DZIĘCZKOwSKI A. 1988. Zespoły ślimaków (Gastropoda) zbiorowisk leśnych Polski. Studium ekologiczne. Prace Komisji Biologicznej PTPN Poznań 48: 1-117.

GŁOWACIŃSKi Z. 1968. Rezerwat „Hańcza” na Suwalszczyźnie. Chrońmy Przyrodę Ojczystą 24: 20-30.

ISKRZYŃSKA E. 1986. Obserwacje nad biologią rozrodu dwóch gatunków z rodzaju Vallonia Risso (Gastropoda: Pulmonata: Vallonidae). Diploma thesis, Wrocław University.

Kerney M. P., CAMERon R. A. D., Jungbluth J. H. 1983. Die Landschnecken Nord- und Mitteleuropas. Paul Parey, Hamburg und Berlin.

KUŹNIK-KOWALSKA E. 1999. Life cycle and population dynamics of Discus rotundatus (O. F. Müller, 1774) (Gastropoda: Pulmonata: Endodontidae). Folia Malacol. 7: 5-17.

MORTON J. E. 1954. Notes on the ecology and annual cycle of Carychium tridentatum at Box Hill. Proc. Malac. Soc. Lond. 31: 40-46.
PokRYszKo B. M. 1990a. Life history and population dynamics of Vertigo pusilla O. F. Müller, 1774 (Gastropoda: Pulmonata: Vertiginidae), with some notes on shell and genital variability. Ann. Zool. 43: 407-432.

POKryszKo B. M. 1990b. The Vertiginidae of Poland (Gastropoda: Pulmonata: Pupilloidea) - a systematic monograph. Ann. Zool. 43: 133-257.

Pokryszko B. M., CAmeron R. A. D. 2005. Geographical variation in the composition and richness of forest snail faunas in northern Europe. Rec. Western Austr. Mus., Supplement 68: 115-132.

RĄKOWSKI G. 1989. Suwalski Park Krajobrazowy. Przewodnik Przyrodniczo-Krajoznawczy. Wydawnictwo PTTK Kraj, Warszawa.

RIEDEL A. 1988. Ślimaki lądowe Gastropoda terrestria. Katalog Fauny Polski 36. PWN, Warszawa.

WÄREBORN I. 1969. Land molluscs and their environments in an oligotrophic area in southern Sweden. Oikos 20: 461-479.

WÄREBORN I. 1979. Reproduction of two species of land snails in relation to calcium salts in the foerna layer. Malacologia 18: 177-180.

WÄREBORN I. 1982. Environments and molluscs in a noncalcareous forest area in southern Sweden. Department of Animal Ecology, University of Lund, Sweden. Dissertation 198, Lund.

WHITNEY M. E. 1938. Some observations on the reproductive cycle of a common land snail, Vallonia pulchella. Influence of environmental factors. Proc. Indiana Acad. Sci. 47(1937): 299-307.

WikTOR A. 2004. Ślimaki lądowe Polski. Mantis, Olsztyn.

Received: January 10th, 2006

Accepted: March 12th, 2006 